$<$ 特 集 $>$

\title{
座談会
}

\section{B 型肝炎治療をめぐる諸問題}

\section{熊田 博光 ${ }^{1) *}$ 進藤 道子 ${ }^{2)}$ 四柳 宏 ${ }^{3)}$ 黑崎 雅之 ${ }^{4)}$ 保坂 哲也 ${ }^{11}$ \\ （*司会 \& corresponding author)}

収録 2011. 1. 8, 13:00-14:00, 於肝臓学会事務局

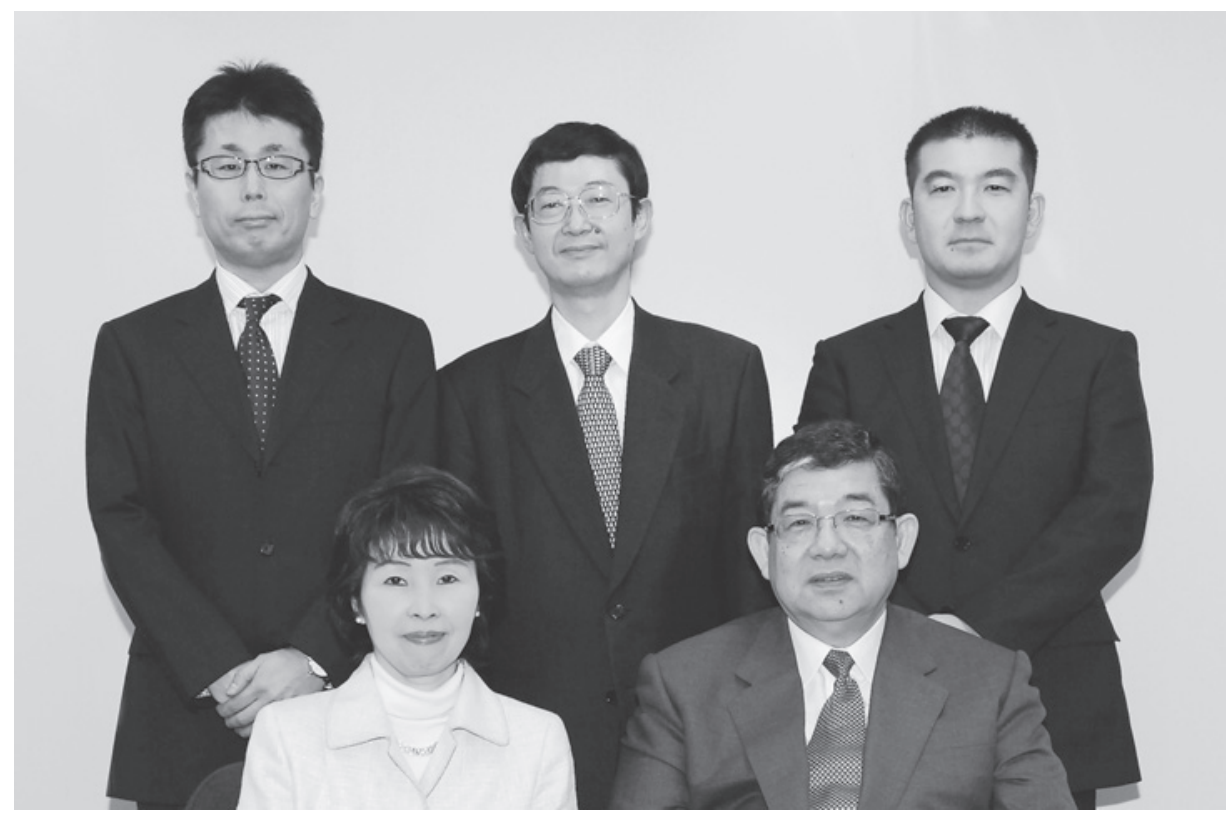

進藤道子/熊田博光 (前列), 黑崎雅之/四柳宏/保坂哲也（後列）

1）虎の門病院肝臓センター，2）明石市立市民病院肝臓内科，3）東京大学大学院生体防御感染症学，4）武蔵野赤十字病 院消化器科

\section{$<$ Feature Article $>$}

\section{Round-table discussion: Various problems over hepatitis B treatment}

Hiromitsu Kumada ${ }^{1)}$, Michiko Shindo ${ }^{2)}$, Hiroshi Yotsuyanagi ${ }^{3}$, Masayuki Kurosaki ${ }^{4)}$, Tetsuya Hosaka ${ }^{1)}$

${ }^{1)}$ Toranomon Hospital, ${ }^{2)}$ Akashi Municipal Hospital, ${ }^{3)}$ Tokyo University Graduate School of Medicine,

${ }^{4)}$ Musashino Red Cross Hospital

(*corresponding author: kumahiro@toranomon.gr.jp) 


\section{はじめに}

熊田：お忙しいところ，扔集まり頂きありがとうござ います.今日は 4 人の先生方に打越し頂きまして, 「B 型肝炎治療をめぐる諸問題」というテーマで座 談会を行ってまいります。

B 型肝炎は C 型肝炎に比べて歴史が古く, 1960 年代の中ごろにBlumberg らがウイルスを発見しま した，それから少し遅れて治療が始まったわけで すが, B 型肝炎治療の歴史について, 進藤先生から 少しお話を聞かせてください.

\section{$\mathrm{B}$ 型慢性肝炎治療の歴史}

進藤：B 型慢性肝炎の抗ウイルス療法は, 日本では 1986 年に interferon（IFN） $\beta$ が初めて認可され，2 年遅れて 1988 年に IFN $\alpha$ が認可されました (Fig. 1). 当時は IFN の投与は 28 回しか行うことができ なかったので,この 28 回の投与から最大限の治療 効果を得るために連日投与, 隔日投与, 2 週間毎の 間歇投与など, 様々な投与法が行われていました. そのころは, HBs 抗原消失を治療の最終目標とす ることは非常に難しかったので， HBe 抗原消失， HBe 抗体へのセロコンバージョンを目指した治療 法が検討されていました，その中にステロイドリ バウンド療法も入っています。このような IFN 単独による治療が 2000 年まで続きました，約 14 年間も B 型慢性肝炎の治療薬には IFN しかなかっ たのですが, 2000 年に lamivudine という経口の抗 ウイルス剤が認可され，核酸アナログの時代が到 来しました. Lamivudine は欧米では日本より 4 年も前から使用されており，良い治療効果が得ら れていました．同時に，2000 年から IFN $\alpha ， \beta$ の 24 週間投与が保険で認可されました.

Lamivudine は抗ウイルス効果が強く副作用が少 ないのですが，唯一耐性変異株出現という大きな 問題がありました。この耐性変異株を抑制するた めに, adefovir という薬が lamivudine に add on という形で 2004 年に認可されました. そして 2006 年には lamivudine のもつ高い変異株出現率という 弱点を克服した，非常に変異株出現率の低い (genetic barrier が低い) entecavir という薬が認可さ れました。これらは欧米とほぼ同時に認可されて
います.さらに, 2008 年には, pegylated interferon （peg-IFN） $\alpha$ の治験が始まり, 同時期に adefovir の単独投与が認可されました.

B 型慢性肝炎治療の変遷を振り返ってみますと, IFN 単独投与の時代が約 10 年ありました. その間 の IFN 治療は, HBe 抗原陰性化率は約 20３0\% と低く，かつ副作用が多く，疾患のコントロール はかなり難しいという印象でした。しかし，この lamivudine という核酸アナログ製剤が登場したこ とで, B 型慢性肝炎の治療に新しい風が吹き込まれ ました，同時に変異株という問題も出現しました が, entecavirの登場でその弱点が克服されると， $\mathrm{B}$ 型慢性肝炎という疾患がコントロール可能な状況 になりました。そして核酸アナログ製剂時代が本 格的に到来したというわけです。しかし，約 10 年経過した今，核酸アナログ製剤治療にも色々な 問題があることが浮き彫りになってきました．

熊田：進藤先生に, B 型慢性肝炎治療の歴史を括話して いただきました. IFN $\beta$ が承認された当時, 4 週投 与では, IFN の治療効果は本当にあるのだろうか ということを皆さんお考えになったのではないで しょうか. しかし, その後, 飯野先生のご尽力に より IFN の 24 週投与が承認され，そこでやっと B 型肝炎に対する IFN 治療が日の目をみたという ような歴史があります。

\section{HBV genotype の有用性}

熊田：一方，B 型肝炎ウイルス（HBV）の HBV DNA や HBe 抗原, HBV genotype, 当時は subtype と呼ばれていましたが，このようなウイルス側の 発見により, B 型慢性肝炎の予後が違うということ も盛んに議論されるようになりました. B 型肝炎の ウイルスマーカーである HBs 抗原の subtype, 今 でいう genotype ですが, その subtype に関して, 四柳先生いかがですか.

四柳：以前の HBs 抗原 subtype は, 現在の genotype A から Jに一対一で対応しているわけではありま せん.しかし，当時の $\mathrm{adr}$ と呼ばれていた HBs 抗原 subtype は, 今の genotype $\mathrm{C}$ にほぼ対応し， adw は現在の genotype B にほぼ対応するので, お およそ当時に出された成績と同様の成績がトレー スできると思います。

熊田：当時の subtype は, 特に日本では adr と adw 


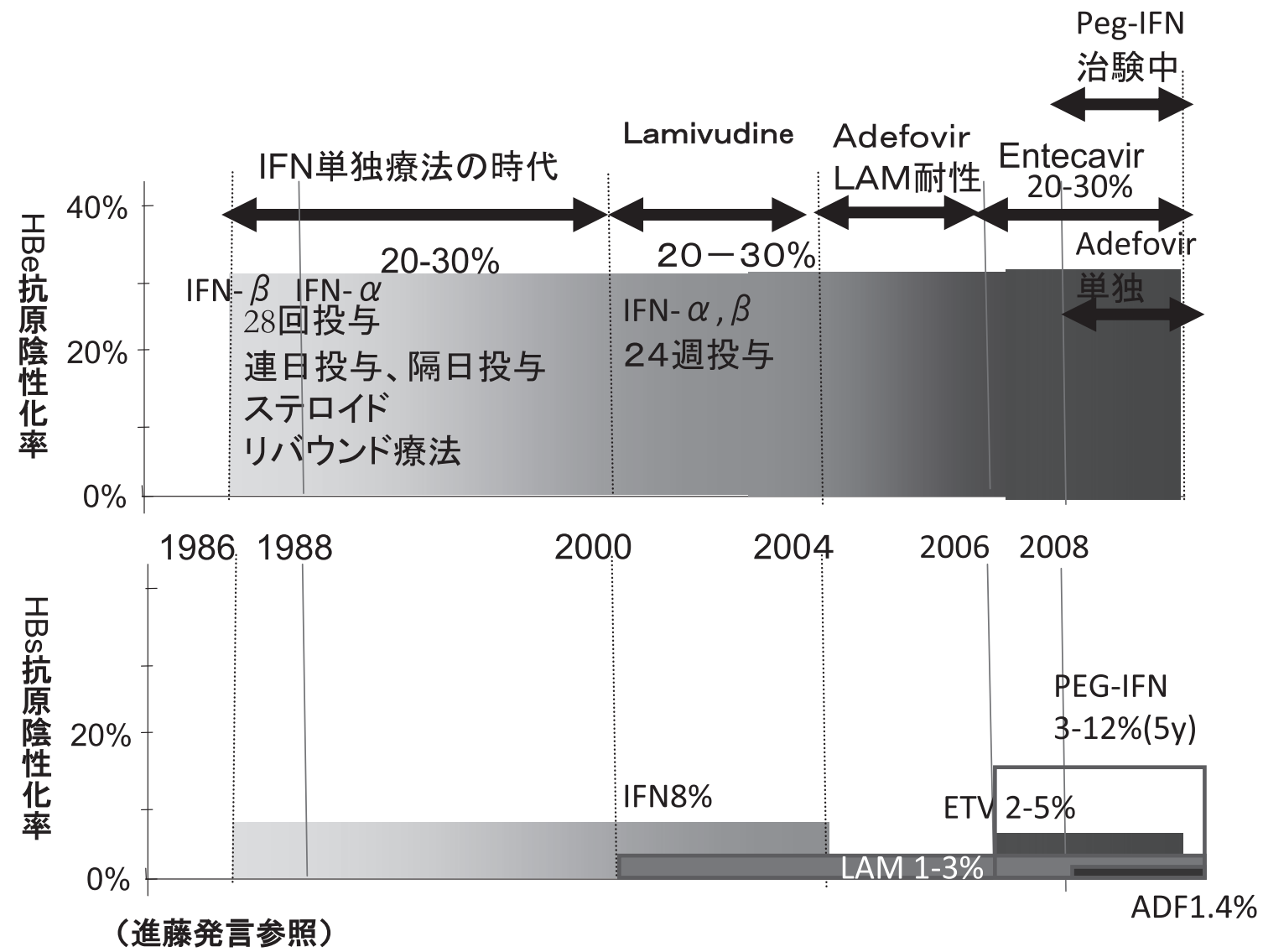

Fig. 1 日本における B 型慢性肝炎治療の変遷

が主体でした，今，四柳先生が言われたように， 以前のサブタイプ adr は現在の genotype C に入り ます. Subtype adw は genotype B もあれば genotype A もあり C もある. Subtype よりも genotype のほうがわかりやすいだろうということで，世界 が genotype に統一されました. 四柳先生, 現在の 日本の genotype の頻度はいかがですか.

四柳：急性の一過性感染の患者さんと, 慢性のいわゆ る持続感染の患者さんで頻度は違います．急性肝 炎の成績では, genotype A の分布は 5 割強, 次い で genotype $\mathrm{C}$, genotype B という順番になってお ります。慢性肝炎では, 東日本と西日本で分布が 異なります。また, genotype Bのキャリアが多い 県は, 秋田県, 山形県, 新潟県, 沖縄県ですが, そのほかの都道府県では genotype C が多いです. 恐らく東日本では 9 割強くらいが genotype C, 西
日本ではその割合がもう少し高いのではないかと 思います。

熊田：以前, 日米肝炎会議において, 欧米では B 型慢 性肝炎は治癒する, IFN 投与により HBs 抗原が消 えてしまう症例があると言われましたが, 日本で はそのような状況はありませんでした。今から考 えると,それは genotype の差であろうと推定され ます.つまり genotype A, D は IFN の反応が非常 に良好で,一部の症例では HBs 抗原が消失する場 合がある.しかし, genotype の C と Bでは, HBs 抗原が消えるというのはなかなか存在しないとい うことがいわれています。

日本では従来, genotype C と B が多かったので すが, 最近は genotype A が増えてきています. 黒 崎先生の施設では, 最近の genotype の傾向はいか がですか. 
黒崎：最近 10 年間の genotype をみますと, genotype A は 11\%, genotype C は 70\%, genotype Bが 18\% です.ただし，急性肝炎に限定すると，最近は $50 \%$ が genotype A です．急性肝炎では genotype A の比率が増えていますので, 今後は慢性肝炎でも genotype Aの比率が徐々に増えていくのではない かと考えています.

熊田：先生の施設では, genotype A による急性感染の 慢性化率はどれくらいですか.

黒崎：Genotype A の急性肝炎では, genotype B や C と比較して ALT 值の異常值が遷延し, HBV DNA 量の減少が遅く, HBs 抗原の陰性化も遅くなりま す. 当院では経過が遷延化した genotype A の症例 に対しては, 積極的に核酸アナログを使っており ますので，幸いなことに現在まで慢性化した症例 は 1 例もなく, 全例で HBs 抗原の陰性化を確認で きています.

熊田：ところが, 実際には昔なかった genotype A の慢 性肝炎が $11 \%$ 存在する。

黒崎：そうですね.

熊田：そのような人たちは, 知らないうちに慢性化し ている可能性がある.

黒崎：その可能性はあると思います．先程お話しした ように, 発症時から当院で経過を観察している急 性肝炎の慢性化はないのですが, 他院から B 型急 性肝炎の経過が遷延するために紹介された症例で, 肝生検で慢性肝炎が確認された症例があります。

\section{IFN の有用例の選択}

熊田：B 型肝炎では genotype の問題がありますが, 今 日は治療をめぐる諸問題ですので, 治療にスポッ 卜を当てていきたいと思います．IFN の有用性と 今後の使い方に関して, 黒崎先生, ご意見を聞か せてください.

黒崎：IFN 治療のメリットは, 期間を限定した治療が できること，また核酸アナログと違って催奇形性 のリスクがないということが一番大きな点だと思 います.また, 治療の反応が得られてセロコンバー ジョンが起きれば, 8 割以上の方がそのままずっと セロコンバージョンが持続します。ですから，こ の核酸アナログ全盛の時代であっても, 症例を選 べばIFNは非常に有用な治療だと思います．ただ し, 治療効果が得られるのは残念ながら 2 3 割で
すので, どのような人が効きやすいかということ を治療前に予測することが大事だと思います。

IFN 治療の効果と関連する因子については多数 の報告があります (Table 1)，若年で，ALT 值が 高く, 肝炎活動性が高い症例は効きやすいという ことが，ほぼコンンサスが得られていると思い ます，肝臓の線維化に関しては, 日本では線維化 が進行している症例では効きにくいというデー夕 が多いのですが，海外では線維化が進行している 症例でも, 同等の治療効果が得られるというデー 夕もあります。 ウイルス側の因子としては, ウイ ルス量が少ないほうが効きやすく,また genotype は IFN 治療効果と非常に関係があり, 年龄とは関 係なくgenotype A, B は効きやすいという成績で す. 若年で ALT 值が高く, HBV DNA 量が少ない 症例が最も良い適応ですが，これらの条件に該当 しなくても genotype を測定することで治療効果が 得られやすい症例を絞り込むことができるため, 非常に重要なファクターだと思います.

熊田：Genotype 以外に, プレコア, コアプロモーター 変異に関しては, 先生はどんなご意見を持ってらっ しゃいますか.

黒崎：当院の成績ではプレコア, コアプロモーター変 異と治療効果には明確な関連がみられませんでし た. 文献でも, 変異型は治療効果が高いという報 告と差がないという報告があるためデー夕は一致 しておらず，現時点では一定した見解がないと私 は理解しております.

熊田：それに関して四柳先生はいかがですか.

四柳：日本の症例の多くは先程申し上げた通り genotype C が優位ですが, 肝炎を起こしている段階ではほと んどの症例に, コアプロモーターの変異が認めら れます。

以前, 私たちがまとめたデータでは, プレコア 変異の症例では比較的肝炎が沈静化しやすく, IFN がどちらかというと効きやすいという傾向があり ました．しかし，必ずしもきれいに分かれるわけ ではありません，いずれにしてもプレコア，コア プロモーター変異だけでIFN の効果を判断するの は，難しいと思います。

熊田：実際の診療では, プレコア, コアプロモーター 変異検出の保険は通っておりますが，なかなか有 効利用できないというのが現状ではないかと思い ます. 
Table 1 インターフェロン治療効果と関連する因子

\begin{tabular}{|c|c|c|c|c|}
\hline 関連因子 & HBe 抗原陽性 & 文献 & HBe 抗原陰性 & 文献 \\
\hline 年齢 & $\begin{array}{l}\text { 若年 } \\
\text { （関連なし） }\end{array}$ & $\begin{array}{l}\text { Pro : Zhao Clin Infect Dis } 2007 \\
\text { Pro : Suzuki J Gastroenterol } 2004 \\
\text { (Con : Krogsgaard J Hepatol 1994) } \\
\text { (Con : Chow Hepatology 2005) }\end{array}$ & 若年 & $\begin{array}{l}\text { Pro : Bonino Gut } 2007 \\
\text { Pro : Lampertico Hepatology } 2003 \\
\text { (Con : Suzuki J Gastroenterol 2004) }\end{array}$ \\
\hline ALT & 高值 & $\begin{array}{l}\text { Lau N Engl J Med } 2005 \\
\text { Hoofnagle Gastroenterology } 1988 \\
\text { Lok Gastroenterology } 1992 \\
\text { Janssen Lancet } 2005 \\
\text { Suzuki J Gastroenterol } 2004\end{array}$ & （関連なし） & $\begin{array}{l}\text { Pro : Bonino Gut } 2007 \\
\text { (Con : Suzuki J Gastroenterol 2004) } \\
\text { (Con : Lampertico Hepatology 1997) }\end{array}$ \\
\hline 肝炎活動性 & 高度 & $\begin{array}{l}\text { Perrillo N Engl J Med } 1990 \\
\text { Brook Hepatology } 1989 \\
\text { Shindo J Gastroenterol } 2004\end{array}$ & 関連なし & Bonino Gut 2007 \\
\hline 肝線維化 & $\begin{array}{l}\text { 軽度 } \\
\text { (高度) }\end{array}$ & $\begin{array}{l}\text { Pro : Shindo J Gastroenterol } 2004 \\
\text { (Con : Buster Hepatology 2007) }\end{array}$ & 関連なし & $\begin{array}{l}\text { Suzuki J Gastroenterol } 2004 \\
\text { Bonino Gut } 2007\end{array}$ \\
\hline HBVDNA 量 & 低值 & $\begin{array}{l}\text { Perrillo N Engl J Med } 1990 \\
\text { Brook Hepatology } 1989\end{array}$ & $\begin{array}{l}\text { 低値 } \\
\text { (関連なし) }\end{array}$ & $\begin{array}{l}\text { Pro : Bonino Gut } 2007 \\
\text { (Con : Lampertico Hepatology 1997) } \\
\text { (Con : Suzuki J Gastroenterol 2004) }\end{array}$ \\
\hline 人種 & 関連なし & $\begin{array}{l}\text { Perrillo N Engl J Med } 1990 \\
\text { Krogsgaard J Hepatol } 1994 \\
\text { Chow Hepatology } 2005\end{array}$ & 関連なし & Bonino Gut 2007 \\
\hline Genotype & $\mathrm{A}, \mathrm{B}>\mathrm{C}, \mathrm{D}$ & $\begin{array}{l}\text { Zhao : Clin Infect Dis } 2007 \\
\text { Janssen Lancet } 2005\end{array}$ & $\mathrm{~A}, \mathrm{~B}>\mathrm{C}, \mathrm{D}$ & Bonino Gut 2007 \\
\hline
\end{tabular}

(黒崎発言参照)

それでは，IFN の投与期間の問題，どのような 患者さんで効果が得られるかという話に移ります. IFN の投与期間別にみた治療成績について, 保坂 先生から少し示していただけますか.

保坂：当院における IFN 治療では, さまざまな投与期 間の患者さんがいらっしゃいます．やはり，IFN の投与期間が長くなればなるほど治療効果が高く なります．特に 1 年以上の投与期間では，著効と いいますか, IFN に反応する率が 3 割以上になっ てきます。現在, 保険上では IFN の投与期間は半 年までですが, 基本的には長く使ったほうが著効 率は高くなると思います.

熊田：日本における 24 週間投与の治療成績はあまり報 告されておりませんが, 当院では $20 \%$ というデー 夕を発表しています。当院での 1 年投与の治験に おけるデー夕はすでに論文化され，1 年の IFN
の間歇投与における著効率は $31 \%$ であると発表し ています。そろそろ peg-IFN $\alpha-2 \mathrm{a}$ の治験が終了し て申請する段階ですので, 来年以降, peg-IFN $\alpha$ $2 \mathrm{a}$ であれば少なくても 1 年は使うことができます. IFN も新たな治療の手段が出てきますので, 今後 の治療に期待したいと思います.

しかし, IFNの治療で効果が得られる症例は, C 型肝炎のように IFN で抑えこんだまま良くなる 治り方と, IFN 終了後にALT 值がリバウンドして 良くなる治り方があります，以前よく言われたの は，自然に消えていくのはナチュラルではないか と. IFN による治療効果があった症例は, リバウ ンドする症例なのか, それとも抑えこむ症例なの か, これらの症例の比率や程度に関して, 進藤先 生の経験ではどのように考えますか.

進藤：そうですね. 成書ではリバウンドを起こして, 
いわゆる withdrawal hepatitis の症例が多いと書か れていますし，私たちもそのように思っていまし た. 実際, 当院の症例で調べてみたところ, 多く の人は acute exacerbations を起こしたとき,もし くはALT 值が高いときにIFN の治療を行うと, 治療効果が高いことが判明しています.

熊田：ナチュラルではないかということですよね.

進藤：同じ人でコントロールスタディができないので, そのところはよくわかりません.

熊田：黒崎先生はいかがですか.

黒崎：そうですね，進藤先生と同じ意見ですが，治療 開始前に ALT 值が高い症例では, 治療中の治療反 応性も良好でウイルス量や HBe 抗原量の減少が得 られやすいのですが，それとは別に治療終了後に リバウンドを起こして治癒する症例もあります.

熊田：リバウンドを起こして消えるのか，それとも起 こらないで消えていくのか, どのような比率だと 思いますか.

黒崎：当院の成績では, 治療中の反応がなくて治療終 了後にリバウンドを起こして治る症例の頻度は低 く，治癒した症例のうち $10 \%$ にすぎません．

熊田：B 型慢性肝炎に対する IFN 治療は, 今後, 1 年 投与が可能になりますので，その段階で再度日本 における治療法を考えていく必要があると思いま す.しかし, 欧米ではすでに genotype A と D に対 して IFN の反応性が良好であることが明らかになっ ています。また, 今後, genotype の測定も保険で 認可される可能性が高いと思いますので，通常の 日常診療で genotype を測定し, genotype A ある いはB の場合は, IFNによりドラッグフリーを目 指した治療ができるようになる.しかし, genotype Cに関しては, 現在のところ IFN での効果は極め て悪いことは事実であります. Genotype C の HBe 抗原陽性症例に対して, 何か治療の工夫はありま すか, 四柳先生.

四柳：まず先程熊田先生がお尋ねになった件ですが, 日本では，IFNを投与してリバウンドが起きる症 例は，個人的には恐らく 1 割くらいはいるのでは ないかと思います。そのような症例は確かに寛解 に至る可能性は高いです，しかし，多くの症例は リバウンド後に寛解に入るわけではありません．

IFN の終了後, 宿主免疫の力とウイルスの増殖力 の間でしばらくは闘いをして，ウイルスの増殖を 抑えながら寛解に入る症例です。特に genotype
C は, 恐らく 2 割弱くらいしか IFN に反応しない と思いますが，その多くは宿主免疫とウイルス増 殖の間で「おしくらまんじゅう」をしながら寛解 に入ります。そうすると, 難治例に対しては, 宿 主の力がウイルスの増殖力を押し負かすような治 療法を考えなければいけません，その一つの方法 は, IFNを長期に続けて, 宿主の免疫機能を up regulateする治療法です. また, もう一つの方法と しては, sequential 療法で, 核酸アナログを先に投 与してウイルス量を減らし, IFN で宿主の免疫力 を上げる治療法です。

熊田：C 型肝炎では, ウイルス量やウイルス変異が治療 に大きく関係することが以前から議論され，一昨 年には宿主側の IL 28B が治療に大きな意味を持つ ということがわかってきました. B 型肝炎において も, すでに報告が出ていますが, 治りやすい SNP を持つ人と治りにくいSNP を持つ人といった話題 が, 今後さらに議論される可能性が高いのではな いかと思います.

\section{Entecavir, lamivudine+adefovir 併用療法の耐性 変異出現率と tenofovir の必要性}

熊田：続きまして，IFN の治療では限界があるという ことが明らかになっていますので，核酸アナログ の話題に移りたいと思います．核酸アナログの全 体の成績について, 保坂先生打願いします.

保坂：当院の成績になりますが, 現在の標準治療であ る entecavir, 核酸アナログ naïve 症例に対する entecavir 治療は，515 例行っています．投与開始か ら 2 年, 3 年経過の HBV DNA 除性化率は, 以前 の Amplicor 法で $94 \%$, TaqMan では 2 年で $64 \%$ 強が除性化し, 抗ウイルス効果は非常に良好です. naïve 症例の耐性変異の出現頻度は, 当院でもまだ 515 例中 2 例しか確認されておらず, 非常に低頻度 であります。したがって，核酸アナログ未治療症 例に対しては, entecavir は非常に有効であるとい うことが言えると思います。

以前は lamivudine が標準治療でしたので, lamivudine による治療をしている方もおられます。し かし, 耐性変異の問題があり, 結局 adefovir を併 用投与している例が 367 例, その中で耐性変異が 出現した症例は 17 例あります.そのうち約半分は, adefovir を開始するときに耐性変異が出現していま 
した. 残りの, 17 例中 9 例は adefovir 併用開始後 に耐性変異が出現しています. 頻度としては $2.5 \%$ が adefovir 併用開始後に耐性変異が出ております が，出現頻度としては非常に低いです。

Adefovir の耐性変異出現例では, 必ずしもブレー クスルーを起こすわけではなく, ウイルスが自然 に低下したり,ALT 值が正常に保たれている症例 もかなり見受けられるという特徵があると思いま す. Lamivudine から entecavir に切り替えている 方も増えていますが, HBV DNA が除性化してい る状態で切り替えた症例に関しては, その後 entecavir の耐性変異が出現した症例は 1 例もありませ ん. しかし, HBV DNA が陽性の状態で切り替え た症例では, entecavir の耐性変異が当院では $15 \%$ 出現しています。 というのは, lamivudine を投与 している症例では, 耐性ウイルスが潜んでいる確 率が高くなります，特に， ウイルス量が多くなる にしたがって耐性ウイルスが出現する頻度が高く なるので, やはり lamivudine で HBV DNA が陰性 化していない症例では, entecavirへの切り替えは 難しいと思います。しかし，陰性になっている症 例では, entecavirへの切り替えが有効だと考えて います。

日本では現在, 3 剂の核酸アナログ製剂が使用さ れていますが, 3 剂とも耐性になってしまった患者 さんが当院では 3 例あります。 これは当院で核酸 アナログを使用している患者さんの $0.18 \%$ にあた ります.非常に低頻度ですが, 耐性になってしまっ た 3 例中 1 例では tenofovir を投与して, 治療が良 好になっています。今後このような多剤耐性の方 が出てきた場合, tenofovir を投入していくのが良 いのではないかと思います.

熊田：黒崎先生の施設はいかがですか.

黒崎：核酸アナログ治療 naïve の症例に対して entecavir を使った症例では, 当院では 1 例だけ entecavir 変異株が出ました. しかしそれは他院で短期間 lamivudine を反復投与されていた既往のある方でした. Entecavir 治療開始時には lamivudine はすでに投 与が中止されており，耐性ウイルスがいないこと を確認してから entecavir 開始しました. しかし 1 年以内に耐性が出てしまいました.この症例では, すでに潜在的な lamivudine 耐性ウイルスが存在し ていたと考えます。その例外的な症例を除きます と, naïve からの耐性例は 1 例もないです.
また, lamivudine 耐性に対して adefovir を併用 した症例では, 当院で継続して治療している症例 からは現時点では 1 例も耐性はありませんが, 紹 介でいらした患者さんで 3 剂耐性の方が 1 名いま す。この方は, 現在は entecavir と adefovir の併用 療法を行っていますが, ウイルス量が $3 \log \sim 4 \log$ で推移し除性化していません，しかし幸いなこと に強い肝炎は起こらず, ALT 值が 30４0ですので, 現在は entecavir と adefovirの併用療法を継続して 経過観察中です。しかし，このような症例で肝炎 が増悪した場合には, tenofovir が必要になると考 えております。

熊田：日本は, 海外より約 4 年遅れの 2000 年に lamivudine が承認されました，海外では lamivudine の耐性株が出た症例に関しては, adefovir に切り替 えるというガイドラインでした. 日本では逆に, lamivudine の耐性株に対しては adefovir を併用す るというガイドラインにしました. ガイドライン での lamivudine + adefovir 併用療法の推奨を世界 より早く行ったということが, 日本の肝炎治療で は非常に大きなことだったのではないかと思いま す. 昨年, 海外も同様に lamivudine の耐性株には lamivudine と adefovir の併用, あるいは tenofovir の併用という, 2 剂併用の治療に変わりました. 今 の括では, 少なくても entecavir の naïveへの耐 性は極めて少なく, lamivudine の耐性に adefovir を使えば大部分のものは良好であるということで すが, 進藤先生はいかがですか.

進藤：それはまったく同じです。

熊田：四柳先生, 新たに entecavir の naïve からの耐性 症例や, lamivudine, adefovir の併用をして両剤の 耐性が出たような症例のご経験はありますか.

四柳：いえ，私の施設ではありません.

熊田：そうなると，これだけ多数の患者さんを見てい る施設が集まっても耐性の症例があまりないとい うことは, 少なくとも現在の日本の核酸アナログ 治療は, 3 剂あれば大部分は治療が可能であるとい うことになると思います. しかし, 未来永劫この 状態が続いていくわけではないので, 次の一手と しての tenofovir が必要になる症例は徐々に増えて くるだろうというのが推定できます．他の症例も tenofovir を使ったら感度以下になっているわけで す.最長で tenofovir はどのくらい使っていますか. 保坂 : 最長は, 約 2 年ぐらいですね. 
熊田：約 2 年ですか, 現時点で. 2 年間で 3 片耐性に tenofovir と entecavir の併用を行って, 変異は出て おらず, ウイルスも抑えられている.海外では tenofovir が使える国がどんどん増えていますので, 今 後, tenofovirの必要性の頻度や効果について, 日 本でも考えなければいけないだろうと思います。

進藤：先生, いいですか. tenofovirの 5 年の成績で, HBs 抗原の消失率が $8 \%$ と出ていました，核酸ア ナログの中ではかなり高いのです。そういう方面 からみると tenofovir は必要なのではないでしょう か.

熊田：実は，当院における lamivudine の 10 年の累積 HBs 抗原消失率は以前の R-PHA 法だと $13 \%$ で, 論文化もされています.より高感度の現在の CLIA 法ですと 10 年で $7.3 \%$ になります. 核酸アナログ は, 実は長く使用していると HBs 抗原の消失がで てきます．現在，当院において核酸アナログ使用 の 33 例で HBs 抗原が消失しています. ですから, tenofovir が必ずしもいいという意味ではなく, 核 酸アナログを長期に使用すれば, HBs 抗原消失が みられてきます。

\section{核酸アナログ中止基準と核酸アナログ・IFN se- quential 療法の有用性}

熊田：さらに，核酸アナログのもう一つの問題点とし て，いつまで使用するのかということです，核酸 アナログの中止基準について, 現在, 信州大学の 田中先生を中心に厚生労働省の班が構成され, 議 論がなされています，核酸アナログの中止につい て，進藤先生は具体的には何かされていますか.

進藤：HBe 抗原陽性症例と HBe 抗原陰性症例とは違い ますが, HBe 抗原陽性症例ではやはり HBe 抗原の 消失とセロコンバージョンが基準になります。そ れが得られない場合は，核酸アナログを中止する のは難しくなります

熊田：HBe 抗原陽性から陰性化して, 長期にわたり陰 性化が持続した場合に核酸アナログを中止した症 例で, 再燃率はどのくらいですか.

進藤：当院では, HBe 抗原の陰性化, セロコンバージョ ン後半年間使用していますが, 治療終了後 6 力月 後に判定すると 7 割は良好です.

熊田：3 割しか再燃していないということですね. 黒崎 先生の施設はいかがですか.
黒崎：当院では, HBV DNA を持続的に陰性化させる ことが重要と考えており, 基本的には長期継続治 療をする方針ですので, 中止例自体が少ないです. 挙児など患者さんの希望で中止する場合以外でも， 治療を離脱するために積極的に中止する基準は, 自然経過でも治るところを核酸アナログで後押し したような症例です。つまり強いシューブに対し て核酸アナログを使って, 結果として非常に早期 にセロコンバージョンを起こして, ウイルスが陰 性化したような症例では, 中止後の経過も非常に 良好です。

熊田：Lamivudine に限らずどの核酸アナログでも良い のですが, 中止して 2 年ぐらい経過したときの再 燃率はどうですか.

黒崎：やむをえず中止した症例も含めた全体では，約 8 割が再燃しています.

熊田：四柳先生の施設はいかがですか.

四柳：私のところは原則として, lamivudine をただ中 止するということはしていないです，中止すると きには熊田先生のお話されていたようなことをす るか, あるいは若い人で lamivudine の耐性株がで きているにもかかわらず，漫然と使われているよ うな症例がありますから，その場合は sequential 療法を使って中止するようにしています。原則と しては通常の症例では継続して治療しますし, 中 止するということはやっていないです.

熊田 : 保坂先生はいかがですか.

保坂：当院で,やむを得ず中止した例では, 7 割が再燃 しています.

熊田 : 7 割, $76 \%$ ですね. 田中班でも 70 数\%です. で すから, HBe 抗原陽性でありながら HBe 抗原が消 えて, それで最低 2 年以上フォローした症例だけ で検討すると, 7 割近い人が再燃してくるというの が全国のデータです，進藤先生の施設は，再燃せ ずに経過が良好となるような症例を選んでいます か.

進藤：そうですね. 海外の成績も 8 割は良好ですよね. ただし，フォローアップの期間が向こうはもっと 短く, 治療終了後 6 力月で判定し, 8 割の成績です. 熊田：そのデー夕はもう 8 年です.

進藤：8 年も長期にフォローアップしていると再燃して くるということでしょうか.

熊田 : 75\%くらい.

進藤：75\% 再燃してくる, かなり高頻度ですね. しか 
し，欧米にはそれほど長期に経過をみた報告はな いでしょう。

熊田：Lamivudineが主流だった時代では, 中止後に $76 \%$ が再燃していたので，ぱっとやめるのが難しかっ たと言えます．厚生労働省の研究班でのデータで も，コア抗原が 3.0 以下，な扮かつ HBs 抗原の定 量が 100 以下という条件以外の症例は大部分が長 期使用のデータで，中止により再燃したという結 果でした，私の臨床経験でも同じょうな感じでし たから, 中止基準の設定は難しいと思います.

それでは, なんとか工夫して, sequential 療法で うまくいかないか. 元の方法は Serfaty が発表して, 岡上先生が京都府立大学時代に積極的に報告され ていましたが, sequential 療法を行っても HBe 抗原が消失しない症例は中止によりすべて経過が 不良でした. HBe 抗原が㓌性化して, その後 sequentialに変えた症例では, 約 $50 \%$ が再燃しなかった というデータが報告されています。進藤先生の施 設では, sequential 療法はやっていますか.

進藤 : やってないです.

熊田：四柳先生の施設はいかがですか.

四柳：私たちの施設で発表した症例は急性増悪例なの で, 多少通常の sequential 療法を行った場合と違 いがあります. HBe 抗原の陽性例に関しては, 核 酸アナログの中止の時点で HBe 抗原が残っている 症例はダメです．このような症例では，IFNに切 り替えるとウイルス量がゆっくりではありますが 増えていきます.核酸アナログの中止の時点で HBe 抗原陰性の症例に関しては, 急性増悪例の約半数 は寛解状態を持続します。このような症例では, HBV DNA 量も上がってきませんし, IFN のフェー ズ中にコア関連抗原がゆっくりと落ちてきます.

ですから, IFN のフェーズ中にウイルス排除が持 続している症例を選択しないと, 恐らく sequential 療法はうまくいきません.

熊田：いわゆるITTでみると, 全体としては HBe 抗原 陽性が陰性化した症例だけ観察すると, 半分くら いは良好だろうということですね.

四柳：はい.

熊田：保坂先生は sequential 療法について,いかがで すか.

保坂：当院では, sequential 療法を 13 例に対して行い, 現在 IFN の治療終了まで進んでいます.データと しては, 終了後 HBV DNA 量が上昇してしまった
症例が $31 \%$ あります. その特徵としては, 核酸了 ナログの投与期間が短いことが影響するようです. また，コア関連抗原量が十分に下がっていない症 例においても, sequential 療法を開始すると再燃し やすいです.

熊田：現時点で, 中止後 1 年の経過が最長の症例で, 3 割が再燃していますね. もう少し経過すると， 5 割くらいになるかもしれません. しかし, 核酸ア ナログ単独で中止した群と sequential 療法で中止 した群とでのコントロールスタディを行うことは 難しいので, 過去の核酸アナログの中止例と条件 を同じくして sequential 療法を評価することしか できないのではないかと思います．現在のところ sequential 療法の評価としては, 核酸アナログ単独 で中止をするより良さそうなのではないかという まとめになると思います.

四柳：そうですね. sequential 療法の導入により, 再燃 が起きても，それまでの期間を遅らせることがで きます. B 型慢性肝炎の IFN 療法は 1 回限りの治 療ではなく, 再治療ができますので, 長い目で見 て治療を行うべきだと思います。

\section{HBs 抗原量, コア関連抗原の臨床応用の位置づけ}

熊田：次に HBs 抗原量, コア関連抗原の臨床での位置 づけについて, 議論してまいります.

以前は, HBs 抗原の定量系は, 慢性肝炎では測 定上限を振り切ってしまうことが多く, 臨床応用 が難しかったのですが, 最近では下限, 上限の幅 が大きくなり, 測定が可能になりました。 また, コア関連抗原が保険診療として測定が可能になり ました。これらの臨床的な位置づけについて，四 柳先生はどう思われますか.

四柳：コア関連抗原は, 現在は日本でしか測ることの できない検査です，一方，HBs 抗原の定量は，欧 米でも積極的に行われており, 慢性肝炎の治療効 果の判定として注目されていると思います. 恐ら く欧米の場合には, 日本と違って比較的抗ウイル 効果のいい症例が中心になっています. 12 週の 段階で $2 \log$ drop されている症例だと思いますが, このような抗ウイルス効果が得られている症例で は，長期の寛解が期待できます，今後，日本にお いても成績が積み重ねられていくと思いますが, 早期に HBs 抗原の定量が下がる症例では抗ウイル 
ス効果が得られていると判定してもよいと考えま す。私たちの施設では，急性肝炎という比較的短 期間で観察できる症例ではありますが，治癒する 症例では HBs 抗原量, コア関連抗原量は急性肝炎 発症の 8 週の時点, また発症 12 週の時点など, 非 常に早期に下がっています。順調に HBs 抗原量, コア関連抗原量が減っていく症例では, 治療効果 が非常に高いので, HBs 抗原量, コア関連抗原量 は慢性肝炎の抗ウイルス効果を判定していく上で 良好なマーカーであると思います。

熊田：保坂先生はいかがですか.

保坂：私もやはり抗ウイルス効果を判定する上で, HBs 抗原やコア関連抗原は非常に有用だと思います. 特にHBs 抗原の場合は, 核酸アナログによって数 值が下がっていく症例は非常に少ないので, 多く の核酸アナログ投与例の中から, 強い抗ウイルス 効果が得られ, さらに HBs 抗原消失が期待される 症例を見つけるためには, HBs 抗原が非常に有用 になると思います。

コア関連抗原に関しては，核酸アナログ投与に より大部分が低い值に推移してくるので，その中 から強い抗ウイルス効果が得られている症例を, コア関連抗原だけで見つけることは難しいと思い ます。核酸アナログの中止をコア関連抗原だけで 判定するのが難しいというのは，こういったこと にあると思います，逆に核酸アナログ投与にもか かわらず，コア関連抗原量が下がらない症例では 何かリスクがあると考えられます，当院では，核 酸アナログ投与中に発癌し，発癌した際にコア関 連抗原が下がってない症例というのは，その後の 肝癌の再発率も高いというデー夕を発表しており ます，肝内のウイルスが下がってない症例は，肝 癌が再発しやすい．ですから，リスクファクター としてコア関連抗原を使う手立てもあるのではな いかと思います。

熊田：コア関連抗原は，もともと保険上で認可された 経緯は，核酸アナログの中止基準に使えたのでは ないかということでした. 当時は 4.3 を基準にして いましたが, やはり 4.3 では再燃することが多く， 現在では 3 以下であると信州大学の田中先生が拐つ しゃられています。コア関連抗原は，それだけで 核酸アナログの中止基準にするというのは難しい のではないかと思います。

\section{HBs 抗原の陰性化率}

熊田：C 型肝炎は現在, IFN と ribavirin 療法なども含 めて全ての治療で全体の約 7 割が治癒できるよう になってきました，ところが，B型肝炎は，なかな か治癒, もちろん臨床的な治癒になりますが, HBs 抗原の陰性化を経験することは少ないです，黒崎 先生のご経験では, B 型肝炎全体で HBs 抗原が消 えた人の割合は，自然経過も含めてどのくらいで すか.

黒崎：自然経過を長期間観察して HBs 抗原を測定した データは持っていません. 治療を行った方での HBs 抗原の消失率ですが, 核酸アナログ治療では $1.5 \%$ です．特徵として, 強い肝障害に対して治療を開 始したところ, 非常に反応よくウイルスが消えて, コア関連抗原も陰性化し, HBs 抗原も消失してい ます. 1 例では最終的には治療を中止した後もリバ ウンドはなく, 安定しています。

熊田：IFNではいかがですか.

黒崎：IFN 治療に関しては, HBe 抗原のセロコンバー ジョンが得られる症例が $20 \%$ ですが, その中で核 酸アナログなどの追加治療を行わずに, IFN 治療 後 5 年間までの追跡で HBs 抗原が消えた症例は残 念ながらありません。

熊田：ないですか.

黒崎：はい. しかし, IFN 治療の後に, 肝炎が持続し たために核酸アナログ製剤を投与し，最終観察時 点で HBs 抗原が陰性化した症例を含めると, IFN 治療例の $4 \%$ で HBs 抗原が除性化しています.

熊田：進藤先生, HBs 抗原消失率はどのくらいですか. 進藤：IFN の治療で, 私の施設では $3 \sim 4 \%$ くらいです. 熊田：何例くらいですか.

進藤：IFN治療を行った症例は, 大体 300 例くらいです 熊田：そうすると,HBs 抗原が消失したのは 6〜 7例と いうことですね.

進藤：そうですね，あまり多くないですね．

熊田：核酸アナログではいかがですか.

進藤：核酸アナログはもうすこし悪くて，その半分ぐ らいです。

熊田：保坂先生はいかがですか. HBs 抗原の消失率は.

保坂：自然経過例と治療例を含めると，全体で 5055 例中 231 例，約 $4 \%$ です。 そのうち IFNによる治 療後に HBs 抗原が消失した症例は 10 年で $18 \%$, 


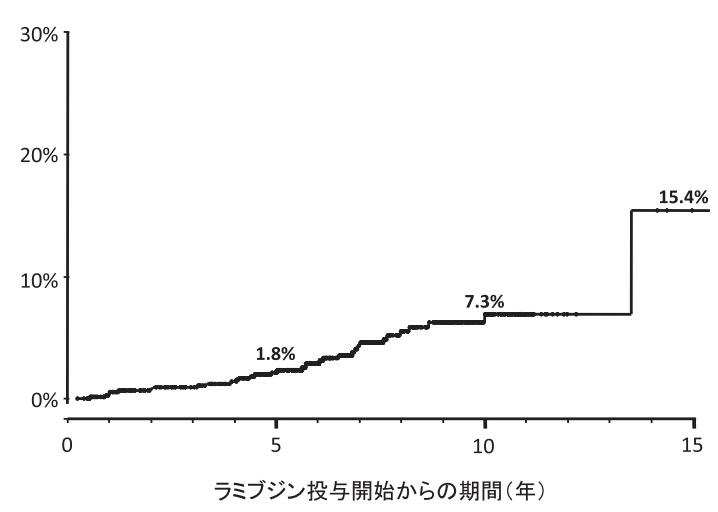

(保坂発言参照)

Fig. 2 ラミブジン投与症例の累積 HBs 抗原消失率

20 年で $36 \%$, 年率 1 2\% くらいです。核酸アナ ログでは 10 年で $7.3 \%, 33$ 例です (Fig. 2).

熊田：IFN は何例のデータですか.

保坂 : 560 例のデータです.

熊田：意外と HBs 抗原消失が少ないように思いますが, 最後までフォローしていると, 結構消失している 例があるのではないでしょうか. かつて順天堂大 学から発表された，国鉄の方たちを対象とした 40 年くらい前のデータで, 私の記憶では 3 割以上で HBs 抗原が消えていたと思います. 20 年のフォロー アップです。国鉄の職員の方は最後まで辞めてい ませんので, 1 例の脱落もなく観察しています.そ うすると, 20 歳代で入った職員で 40 年の経過で HBs 抗原が 3 割の人で消えているのです.

実際の診療では，何らかの都合でフォローアッ プができなくなる患者さんがいますので, 日本の $\mathrm{B}$ 型肝炎の $\mathrm{HBs}$ 抗原陰性化率は, 本当の意味では 脱落がないデータで検討しなければいけないので はないかと思います.

四柳：今までは, HBs 抗原の良い定量系がなかったこ と,また B 型慢性肝炎の HBs 抗原は消えないので はないかという先入観を私たちが持っていたのだ と思います。これからは, HBs 抗原の良い定量系 が出てきましたので, HBV DNA や HBe 抗原が陰 性化した症例に関してはHBs 抗原を測定してみる. そして, 定量值が明らかに下がってきている症例 に関しては丁寧に観察していくことで, 日本の HBs 抗原消失率の全体像を明らかにしていかなければ ならないのではないかと思います。

\section{$\mathrm{B}$ 型肝炎の発癌予防の治療効果}

熊田：最後に, 発癌予防の効果について, 議論してま いります. B 型肝炎では, トランスアミナーゼが正 常, HBe 抗原陰性の症例から発癌がすることがあ ります。発癌予防に関するデータでは, 保坂先生 いかがですか.

保坂：核酸アナログによる発癌の予防効果は, 肝炎の 進行度によって変わってくると思います．特に, 肝硬変のウイルスがある程度多い症例では自然経 過の発癌率が非常に高いです。当院でも，自然経 過でウイルス量が多い症例では, おおよそ 10 年で 5 割くらいは発癌しています. しかし, 核酸アナロ グを投与して，なおかつ耐性ウイルスが出ていな い症例で検討した場合， 5 年で $28 \%$ まで抑えられ ます，また，発癌率の曲線を描くと，徐々に傾き がなだらかになってきます。最初はある程度, 自 然経過で癌の芽がある症例が発癌して, それが徐々 になくなってくると発癌率の曲線も緩やかになっ てくるという特徴があると思います。

熊田 : 肝硬変の発癌について, Intervirologyに最初に 書いた自然経過を 10 年観察したデータがあります. HBV DNA 量が TMA 法で 3.7 log copies/mL 以下 を持続する症例は発癌が極めて少なく, $5.0 \log \mathrm{cop}-$ ies $/ \mathrm{mL}$ 以上の高值を持続する症例は発癌しやすい というデータです．黑崎先生の施設では，いかが ですか.

黒崎：ウイルス量が多いと発癌率が高いということは, 全く同じです.

熊田：それでは, 次に, ウイルス量が多ければ核酸ア ナログの使用により減らすことができますよね. 少なくとも現在の entecavir ではほとんど変異株は でません，そうすると，発癌は抑制できますか.

黒崎：先ほどの保坂先生のお話にもあったように，発 癌リスクの高い症例では核酸アナログでウイルス が消えても,すぐには発癌が減少せず, 3 年以降か ら Kaplan-Meier の曲線が緩やかになります.しか し完全にゼロにはならずに少しずつ発癌する症例 がでます。ですから， ウイルス増殖抑制は発癌抑 止のための十分条件とは言えず, 他の発癌リスク, おそらく宿主側の要因があるのではないかと思い ます.

熊田：核酸アナログを使っているほうが発癌率は上に 
Table 2 ラミブジン治療による発癌の抑止

\begin{tabular}{|c|c|c|c|c|c|c|c|c|}
\hline & $\begin{array}{l}\mathrm{LAM} \\
(\mathrm{n} / \mathrm{N})\end{array}$ & $\begin{array}{l}\text { Control } \\
(\mathrm{n} / \mathrm{N})\end{array}$ & 年齢 & $\begin{array}{c}\text { 肝硬変 } \\
(\%)\end{array}$ & $\begin{array}{c}\text { HBe 抗原 } \\
(\%)\end{array}$ & $\begin{array}{c}\text { 観察期間 } \\
\text { (年) }\end{array}$ & $\mathrm{RR}$ & $95 \% \mathrm{CI}$ \\
\hline Liaw（2004） & $17 / 436$ & $16 / 215$ & 43.3 & 61.3 & 57.8 & 2.7 & 0.52 & $0.27-1.02$ \\
\hline Matsumoto (2005) & $4 / 377$ & $50 / 377$ & 41.5 & 17.5 & 54.8 & 2.7 & 0.08 & $0.03-0.22$ \\
\hline Papatheodoridis (2005) & $5 / 201$ & $15 / 195$ & 50.5 & 33.3 & 0 & 3.8 & 0.32 & $0.12-0.87$ \\
\hline Yuen (2007) & $1 / 142$ & $3 / 124$ & 33.7 & 0 & 100 & 8.2 & 0.29 & $0.03-2.76$ \\
\hline Eun (2007) & $5 / 111$ & $36 / 111$ & - & 100 & - & 4.4 & 0.14 & $0.06-0.34$ \\
\hline 全体 & $32 / 1267$ & $120 / 1022$ & & & & & 0.22 & $0.10-0.50$ \\
\hline 肝硬変 & $17 / 436$ & $71 / 317$ & & & & & 0.17 & 0.04-0.79 \\
\hline 非肝硬変 & $9 / 488$ & $31 / 386$ & & & & & 0.21 & $0.10-0.47$ \\
\hline 耐性非出現例 & $9 / 347$ & $34 / 534$ & & & & & 0.37 & $0.17-0.77$ \\
\hline 耐性出現例 & $14 / 426$ & $34 / 534$ & & & & & 0.52 & $0.28-0.97$ \\
\hline
\end{tabular}

Sung らより改変, 引用 Sung et al. Meta-analysis : treatment of hepatitis B infection reducesnrisk of hepatocellular carcinoma Alimentary Pharmacology and therapeutics $2008: 28: 1067-1077$ (黒崎発言参照)

いくことはないですね.

黒崎：それはないです.

熊田：ないですね.

黒崎：発癌のリスクの少ない人からリスクの高い人ま で条件を同じにそろえて層別化しても，核酸アナ ログを使ったほうが発癌率の曲線は下にきます. もともと発癌のリスクの少ない人では, 治療によ る発癌抑止の効果は有意差がでませんが，発癌リ スクの高い症例では, 核酸アナログ治療で発癌率 が抑制されます。それでも短期間の投与では，発 癌曲線はほとんど重なってしまい, 治療が長期に なり 3〜 5 年が経過し, HBV DNA の陰性化期間が 長くなると, 発癌曲線の差が開いてきます. 最近 のメ夕解析でも, 核酸アナログ治療で発癌が抑止 されると報告されています（Table 2).

熊田：今の核酸アナログを, 発癌してしまった方に再 発予防で使用する，あるいは肝硬変に対して長期 使用していくということは，基本的には行うべき 治療だということになりますか.

黒崎：再発の抑止については現時点ではまだ明確なエ ビデンスはありませんが, 肝機能が改善するため に治療の選択肢が増えることで，生命予後が改善 すると考えられますので，私は治療を行うべきだ と考えます。 また, 肝硬変では発癌の抑止と肝機 能の改善や維持のために, 積極的に長期使用して ゆくべきだと考えています.

熊田：しかし，それだけでは発癌はゼロにならないの
で，さらなる治療法を検討していかなければなり ません.

最後に, B 型の肝癌をなるべく減らすための将来 的な展望について，四柳先生のお考えをお話しく ださい.

四柳：非常に難しい課題です.

今お話が出てきたように, B 型肝炎の場合には, 1 回感染をしてしまうと宿主遺伝子に対して HBV DNA の組込みが起こる可能性があるので, ウイル ス増殖を抑えても発癌リスクがゼロになるという ことは基本的にはないと思います. しかし, ウイ ルス量を極端に落とせば，少なくてもウイルスが 増殖することによる新たなイベントを抑えること が基本的には可能です。すでに，保坂先生がおつ しゃられたような癌の芽ができている症例や，遺 伝子的なイベントができあがった症例については 仕方ありませんが, このようなリスクファクター がなくなっている症例では，恐らく長期にわたり 発癌を抑制できると思います。

また, IFNによる発癌抑止効果に関しては十分 わかっておりませんが, 少なくともマイナスには なることはないと思います。

さらに，現在使える薬ではありませんが，例え ば retinoidのような, 癌の芽になりそうな細胞を逆 に正常な細胞へ分化させていく薬による治療がで きれば，この国の将来展望は大きく変わってくる と思います。それまでは現在のリスク因子を持つ 
人たちを囲い込み，発癌率をできるだけ減らすた めにウイルス量を減らしていくというやり方が, この数年間は最善の治療法だと私自身は感じてい ます.

熊田：HBs 抗原が消えれば, 発癌率は相当減ると思い ますが, 関西では HBs 抗原が消えても発癌する人 が多くいるというような話も聞きました，進藤先 生は HBs 抗原陽性の慢性肝炎, 肝硬変症例で, HBs 抗体にセロコンバージョンした後, 発癌した症例 はどれくらい聞いていますか.

進藤：そのような症例は, 私は経験したことはありま せん. しかし，自然経過で HBs 抗原が消失してい るのに肝癌があるため来院した方はいますから, HBs 抗原が消えても発癌のリスクはあるのだと思 います。

熊田：黑崎先生は, HBs 抗原陽性の方で, HBs 抗原が 消えて, HBs 抗体にセロコンバージョンが起きて なくてもよいのですが，その後発癌したというご 経験はありますか.

黒崎：いわゆる, Non B, Non C の肝細胞癌のなかでの HBs 抗体の比率ですか.

熊田：最初から B 型ということが分かっている状態で.

黒崎：最初から B 型肝炎として継続的に観察できてい る症例で, HBs 抗原が消えてから発癌した症例は
ないですね.

熊田：四柳先生の施設はいかがですか.

四柳：恐らくないです.

熊田 : 保坂先生の施設はいかがですか.

保坂：当院では，さきほどご紹介した 231 例の中で, HBs 抗原が消えた後に発癌した症例が 5 例ありま した．しかし，ほとんどの症例が進行例，肝硬変 です.

熊田：HBs 抗原が消えて, 適切な経過観察を行ってい ても発癌したということですね.

保坂：はい.

熊田：C 型肝炎は治療法がどんどん進み,もうしばらく したら経口薬だけで治癒する時代が来ると思いま すが, B 型肝炎のほうは残念ながらそう簡単にはい きません，ですから，核酸アナログ製剤や IFN を中心に治療を行いながら, 発癌予防といった観 点ではレチノイドの使用や新たな発癌要因を検討 し, 包括的な治療を行っていく必要があると思い ます, 特に一度発癌した方では, 発癌予防は重要 です. 慢性肝炎が肝硬変へ進行する前に HBs 抗原 が消えれば発癌率は相当減りますので, 新たな治 療も期待したいと思っております.

本日はお忙しいところ, どうもありがとうござ いました。

(C) 2011 The Japan Society of Hepatology 